\title{
Extraterritorial Derogations from Human Rights Treaties in Armed Conflict
}

\author{
Marko Milanovic*
}

\section{Introduction}

This chapter does not purport to provide a comprehensive account of the rules and the existing case-law regarding derogations from human rights treaties. ${ }^{1}$ Rather, it examines one specific question: whether states are allowed to derogate from human rights treaties for situations which take place outside their territories, especially in armed conflict. Can the United Kingdom, for instance, derogate from the European Convention on Human Rights (ECHR) or the International Covenant on Civil and Political Rights (ICCPR) for events that take place in Afghanistan and involve its armed forces deployed there, to the extent that the ECHR and the ICCPR apply in Afghanistan?

Derogations allow states parties to depart from the full extent of their obligations in situations of emergency. But no state has ever derogated from a human rights treaty in an extraterritorial setting. The United States did not derogate from the ICCPR with respect to Iraq and Afghanistan, nor did the United Kingdom or any other European state do so under the ECHR. But the relevance of the question

${ }^{*}$ Much of the research for this chapter was done while I was visiting professor at the University of Michigan Law School in Fall 2013, and I am most grateful to the Michigan Law Library staff for their invaluable research assistance, as well as to Haleema Wahid, legal researcher at the University of Nottingham. Thanks are also due to Kjetil Mujezinovic Larsen, Jelena Pejic, Aurel Sari and Stuart Wallace for their helpful comments. The substantive content of this chapter was finalized in June 2014.

${ }^{1}$ For the principal works on the subject, see, e.g. A. Svensson-McCarthy, The International Law of Human Rights and States of Exception (1998); J. Fitzpatrick, Human Rights in Crisis: The International System for Protecting Human Rights During States of Emergency (1994); R. Ergec, Les droits de l'homme à l'épreuve des circonstances exceptionnelles: étude sur l'article 15 de la Convention européenne des droits de l'homme (1987); Higgins, 'Derogations under Human Rights Treaties', 48 British Yearbook of International Law (1978) 281. See also D. Harris et al., Law of the European Convention on Human Rights (2nd edn, 2009), at 617-645; M. Nowak, CCPR Commentary (2nd edn, 2005), at $83 \mathrm{ff.}$

For an argument that existing approaches need to be radically reconsidered, see Sheeran, 'Reconceptualizing States of Emergency under International Human Rights Law: Theory, Legal Doctrine, and Politics, 34 Michigan Journal of International Law (2013) 491. 
I am posing should not be in doubt. The first line of defence for most states engaged in extraterritorial adventures of one kind or another has generally been to deny that human rights treaties apply extraterritorially in the first place. That line is now faltering. Cases regarding the extraterritorial application of human rights continue to pile up, and the treaties are increasingly found to apply by courts and treaty bodies driven by the moral imperative of universality, bounded by pragmatic considerations of effectiveness. ${ }^{2}$ And the wider the geographical scope of human rights treaties, the more relevant the question of extraterritorial derogations becomes. Such derogations might start looking increasingly appealing to states, especially those which have initially miscalculated in arguing that the treaties do not apply at all, and have avoided derogating for fear that doing so would count as an admission that the treaties do apply. Derogations have the potential of bringing both clarity and flexibility to the applicable legal framework, especially in situations of armed conflict and with regard to possible interactions between human rights and international humanitarian law (IHL).

But are extraterritorial derogations even possible in principle? In the Al-Jedda case before the House of Lords, ${ }^{3}$ Lord Bingham recalled that Article 15 ECHR allows for derogations in 'time of war or other public emergency threatening the life of the nation', only to the extent strictly required by the exigencies of the situation, and considered the language of this article as follows:

It is hard to think that these conditions could ever be met when a state had chosen to conduct an overseas peacekeeping operation, however dangerous the conditions, from which it could withdraw. The Secretary of State does not contend that the UK could exercise its power to derogate in Iraq (although he does not accept that it could not). It has not been the practice of states to derogate in such situations, and since subsequent practice in the application of a treaty may (under article 31(3)(b) of the Vienna Convention) be taken into account in interpreting the treaty it seems proper to regard article 15 as inapplicable. ${ }^{4}$

Lord Bingham made two points. Firstly, that the life of the nation-the life of the nation seeking to derogate from the human rights treaty-simply cannot be threatened by an overseas situation which it entered into voluntarily and from which it could withdraw at any time. He refers us to a serious interpretative problem, which I will return to later. His second point is that the absence of any extraterritorial derogations under Article 15 ECHR should be taken into account under Article 31(3)(b) of the Vienna Convention on the Law of Treaties (VCLT) and lead us to the conclusion that such derogations are impermissible. Indeed, in making this argument Lord Bingham was following the lead of the European Court of Human Rights (ECtHR) in Bankovic, which regarded the absence of

2 See generally M. Milanovic, Extraterritorial Application of Human Rights Treaties: Law, Principles, and Policy (2011).

${ }^{3} R$ (Al-Jedda) v. Secretary of State for Defence [2007] UKHL 58, [2008] 1 AC 332 (hereinafter Al-Jedda $H L)$.

4 Ibid., para. 38. 
extraterritorial derogations as evidence that the ECHR should apply extraterritorially in exceptional cases only. ${ }^{5}$

But this argument-very formal as it is-fails on equally formal grounds. Article 31(3)(b) VCLT does not merely refer to the subsequent practice in the application of a treaty, but to such practice 'which establishes the agreement of the parties regarding its interpretation'. Not only is there not even an inkling of any kind of agreement between states parties as to the territorial scope of the derogation clauses, but there are plenty of reasons why states may have not derogated extraterritorially, other than thinking that such derogations were categorically impermissible. They may just as easily have thought that these derogations were unnecessary, as they could obtain the same results through other means, or that doing so would cost them politically. Nor did states give any serious thought to the question of the extraterritorial application of human rights treaties generally until the mid-1990s. ${ }^{6}$

In other words, that states have historically not made any extraterritorial derogations does not ipso facto mean that they could not do so in the future, especially if the need for them arises. And it is in my view more likely than not that such a need will arise, and will become progressively more acute as the approach of courts and human rights bodies with regard to the extraterritorial application of the treaties themselves becomes more generous. If that approach becomes very generous, as I have argued elsewhere it should be, so that (at a minimum) states have the negative obligation to respect human rights which is territorially unbounded, and a positive obligation to secure or ensure human rights whenever they exercise de facto effective control over territory, ${ }^{7}$ then the inability of states to derogate extraterritorially would look increasingly anomalous.

5 ECtHR, Bankovic and Others v. Belgium and Others, Appl. no. 52207/99, Decision on Admissibility of 12 December 2001, para. 62:

The Court finds State practice in the application of the Convention since its ratification to be indicative of a lack of any apprehension on the part of the Contracting States of their extra-territorial responsibility in contexts similar to the present case. Although there have been a number of military missions involving Contracting States acting extra-territorially since their ratification of the Convention (inter alia, in the Gulf, in Bosnia and Herzegovina and in the FRY), no State has indicated a belief that its extra-territorial actions involved an exercise of jurisdiction within the meaning of Article 1 of the Convention by making a derogation pursuant to Article 15 of the Convention. The existing derogations were lodged by Turkey and the United Kingdom in respect of certain internal conflicts (in south-east Turkey and Northern Ireland, respectively) and the Court does not find any basis upon which to accept the applicants' suggestion that Article 15 covers all 'war' and 'public emergency' situations generally, whether obtaining inside or outside the territory of the Contracting State. Indeed, Article 15 itself is to be read subject to the 'jurisdiction' limitation enumerated in Article 1 of the Convention.

6 See also K. da Costa, The Extraterritorial Application of Selected Human Rights Treaties (2012), at 132-135; Roxstrom, Gibney and Einarsen, 'The NATO Bombing Case (Bankovic et al. v. Belgium et al.) and the Limits of Western Human Rights Protection', 23 Boston University International Law Journal (2005) 55, at 117-118; A. Sari, Derogations from the European Convention on Human Rights in Deployed Operations, Written Evidence to the House of Commons Defence Committee, 4 December 2013, available online at http://www.publications.parliament.uk/pa/cm201314/ cmselect/cmdfence/writev/ futureops/law10.htm (last accessed 23 July 2015), paras 17-18.

7 See Milanovic, supra note 2. 
As mentioned above, the permissibility of extraterritorial derogations is especially important in situations of armed conflict which involve the forces of a state but take place outside its territory. That conflict can in terms of IHL be either an international armed conflict (IAC), which is inter-state in character, or a noninternational armed conflict (NIAC), which involves (at least) the forces of the state fighting a non-actor. ${ }^{8}$ The International Court of Justice (ICJ) has famously held in its Nuclear Weapons and Wall advisory opinions that 'the protection offered by human rights conventions does not cease in case of armed conflict, save through the effect of provisions for derogation of the kind to be found in Article 4 of the International Covenant on Civil and Political Rights'. ${ }^{9}$ The Court's holding seems to apply equally to IACs and NIACs.

If IHL and human rights treaties simultaneously regulate the same conduct, and do so in both types of armed conflict, the most difficult question is what to do in situations in which the rules of the two bodies of law themselves arguably conflict. For example, while IHL explicitly allows the status-based targeting of combatants in IACs or fighters in NIACs and of civilians taking a direct part in hostilities in both types of conflict, as well as the preventive security detention of all kinds of individuals, such as prisoners of war, human rights law generally sets more stringent standards on the use of lethal force, permitting it only as a last resort, abhors preventive detention, and mandates judicial review of any detention. ${ }^{10}$ Any analysis of derogations must seek to explain the role they play in mediating norm conflicts between IHL and human rights, and how they fit together with other tools for avoiding or resolving such conflicts, such as the lex specialis principle.

In that regard, I will argue that extraterritorial derogations are not only permissible, but may even be necessary and desirable, as part of the price worth paying for the extensive and effective application of treaties outside states' boundaries. I will focus my discussion on three treaties - the ICCPR, the ECHR and the American Convention on Human Rights (ACHR). ${ }^{11}$ Some of the other human rights treaties explicitly exclude any derogation, such as the Convention against Torture, ${ }^{12}$ while others, such as the International Covenant on Economic, Social and Cultural Rights or the African Charter on Human and Peoples' Rights, simply do not mention

8 The circumstances in which such conflicts can arise are varied, and can be classified under several descriptive subtypes - see further Milanovic and Hadzi-Vidanovic, 'A Taxonomy of Armed Conflict', in N. White and C. Henderson (eds), Research Handbook on International Conflict and Security Law (2013) 256.

9 Legal Consequences of the Construction of a Wall in the Occupied Palestinian Territory, Advisory Opinion, 9 July 2004, ICJ Reports (2004) 136, para. 106. See also Legality of the Threat or Use of Nuclear Weapons, Advisory Opinion, 8 July 1996, ICJ Reports (1996) 226, para. 25.

${ }^{10}$ See further Milanovic, supra note 2, at $229 \mathrm{ff}$.

11 International Covenant on Civil and Political Rights 1966, 999 UNTS 171; Convention for the Protection of Human Rights and Fundamental Freedoms 1950, 213 UNTS 221; American Convention on Human Rights 1969, 1144 UNTS 123.

12 Convention against Torture and Other Cruel, Inhuman or Degrading Treatment or Punishment 1987, 1465 UNTS 85. Art. 2(2) provides: 'No exceptional circumstances whatsoever, whether a state of war or a threat of war, internal political instability or any other public emergency, may be invoked as a justification of torture.' Note that the CAT's provisions hence undoubtedly apply in wartime. 
them. ${ }^{13}$ I make no claim in this chapter with regard to the application during armed conflict of human rights treaties without derogation clauses. I will start by comparing the texts of the three treaties, which exhibit many similarities, but also some important differences.

\section{Interpreting the ICCPR, ECHR and ACHR}

\section{A. Comparing the Texts}

That the derogation clauses of the three treaties-Article 4 ICCPR, Article 15 ECHR, and Article 27 ACHR - are in many respects similar should come as no surprise. They address the same problem, the drafting of the ICCPR and the ECHR mostly overlapped in time, and those drafting the ACHR were able to draw inspiration from the older drafting materials and experiences of the two other treaties. They share the same basic structure. The first paragraph of each of the articles sets up the general power to derogate, and the substantive conditions for the exercise thereof. The second paragraph then specifies that some rights are nonderogable even in the gravest of emergencies. The third paragraph then crafts procedural rules regarding the international supervision of any derogation.

The first paragraphs of each clause are the most important and the most complex, so let us now compare them. Article 4(1) ICCPR provides that:

In time of public emergency which threatens the life of the nation and the existence of which is officially proclaimed, the States Parties to the present Covenant may take measures derogating from their obligations under the present Covenant to the extent strictly required by the exigencies of the situation, provided that such measures are not inconsistent with their other obligations under international law and do not involve discrimination solely on the ground of race, colour, sex, language, religion or social origin.

Article 15(1) ECHR stipulates that:

In time of war or other public emergency threatening the life of the nation any High Contracting Party may take measures derogating from its obligations under this Convention to the extent strictly required by the exigencies of the situation, provided that such measures are not inconsistent with its other obligations under international law.

Finally, Article 27(1) ACHR provides that:

In time of war, public danger, or other emergency that threatens the independence or security of a State Party, it may take measures derogating from its obligations under the present Convention to the extent and for the period of time strictly required by the exigencies of the situation, provided that such measures are not inconsistent with its other obligations under international law and do not involve discrimination on the ground of race, color, sex, language, religion, or social origin.

13 See generally Ouguergouz, 'L'absence de clause de dérogation dans certains traités relatifs aux droits de l'homme: les réponses du droit international général', 98 Revue générale de droit international public (1994) 289. 
We can observe several interesting points of comparison. Firstly, when it comes to defining a situation that enables a derogation, the ECHR and the ACHR explicitly mention 'war', whereas the ICCPR does not.

Secondly, the ICCPR and the ECHR both require a public emergency that threatens, or is threatening, 'the life of the nation', whereas the ACHR requires 'public danger, or other emergency that threatens the independence or security' of the state. At least on the face of it, the ACHR's reference to 'security' seems more permissive than the ICCPR's and the ECHR's threat to the 'life of the nation'. The draft by the Inter-American Commission on Human Rights which ultimately became Article 27 was in fact originally based on the texts of the ECHR and the ICCPR; the 'life of the nation' wording was later dropped for unclear reasons, but apparently without the intention of allowing for more expansive recourse to derogations. ${ }^{14}$

Thirdly, only the ICCPR expressly requires that the existence of the public emergency be 'officially proclaimed'.

Fourthly, all three treaties demand that the derogating measures should not be inconsistent with the state's other obligations under international law. The most obvious body of such obligations in times of armed conflict would be IHL, which would set a floor below which human rights law could not be derogated from. ${ }^{15}$ Indeed, the insertion of this language into the ICCPR was first proposed by the United States precisely in order to take into account the law of armed conflict. ${ }^{16}$

Fifthly, the ICCPR and the ACHR also explicitly require the derogating measures to not be discriminatory on the specified grounds, whereas the ECHR does not.

Finally, under all three treaties the derogating measures must be 'strictly required by the exigencies of the situation', while the ACHR also adds that the measures must be taken 'to the extent and for the period of time' that they are strictly required, with this temporal element only being implicit in the other treaties.

${ }^{14}$ See generally Norris and Desio Reiton, 'The Suspension of Guarantees: A Comparative Analysis of the American Convention on Human Rights and the Constitutions of the States Parties', 30 American University Law Review (1981) 189, at 191-193.

15 See, e.g. Human Rights Committee, General Comment 29, UN Doc. CCPR/C/21/Rev.1/ Add.11 (2001), at paras 3 and 9. See also Buergenthal, 'To Respect and to Ensure: State Obligations and Permissible Derogations', in L. Henkin (ed.), The International Bill of Rights (1981) 72, at 82; Moir, 'Law and the Inter-American Human Rights System', 25 Human Rights Quarterly (2003)182, at 184; Nowak, supra note 1, at 99; Ergec, supra note 1, at 215, 223-230.

16 See Commission of Human Rights, 6th Session, Summary Record of the 195th Meeting, UN Doc. E/CN.4/SR.195, 29 May 1950, at 10, para. 45:

There were fortunately a great many conventions governing the conduct of States in time of war. They included, in particular, the four conventions recently drawn up at Geneva. The United States delegations considered that the Commission [on Human Rights] should take full advantage of those conventions which had been carefully worked out by big international conferences and it accordingly proposed that the text of article 4, paragraph 2, should be replaced by the following: "No derogation may be made by any State under this provision which is inconsistent with international law or with international agreements to which such State is a party.

The wording was later added to paragraph 1, while the list of non-derogable rights in paragraph 2, which the amendment initially intended to replace, remained. 
The textual differences are not insignificant, and for our purposes the most notable is the omission of 'war' from the ICCPR, and the fact that the ACHR does not require a threat to the 'life of the nation'. When it comes to the list of nonderogable rights in the second paragraphs of the derogation clauses, the most obvious difference is that the ECHR's list is the narrowest, the ACHR's the broadest, and the ICCPR's somewhere in between. Thus, the ECHR considers as non-derogable the right to life (but only conditionally), the prohibition against torture and cruel, inhuman and degrading treatment or punishment, the prohibition of slavery, and the prohibition of retrospective punishment without law. The ICCPR adds to this list the prohibition of imprisonment merely because of failure to fulfil a contractual obligation, the right to recognition as a person before the law, and the freedom of thought, conscience and religion. The ACHR finally adds the rights of the family, the right to a name, rights of the child, the right to nationality, and the right to participate in government, as well as the judicial guarantees essential for the protection of such rights. The ACHR's additions were apparently the product of entirely ad hoc drafting within a working group during a 15-minute recess of what was probably no more than an hour-long discussion of draft Article 27. ${ }^{17}$

But the most important difference for our purposes is that while it generally prohibits derogations from its Article 2 on the right to life, the ECHR does allow them 'in respect of deaths resulting from lawful acts of war'. It is the only treaty to do so. And in doing so it creates a clear window through which IHL can enter, as IHL would presumably be the benchmark for testing whether any acts of war were lawful. But despite this opportunity in Article 15(2) ECHR, no state has ever derogated from Article 2, either for purely internal or for IACs, and this part of Article 15(2) has never been interpreted by the ECtHR.

We will come to derogations and IHL later in the chapter, but it must be noted here that the ECHR's permissibility of derogations from the right to life with respect to lawful acts of war is coupled with a significant difference between how the right to life is formulated in Article 2 and how it is set out in the ICCPR and the ACHR. Article 6(1) ICCPR and Article 4(1) ACHR both provide that ' $[n]_{0}$ one shall be arbitrarily deprived of his life'. Article 2(1) ECHR, on the other hand, says that ' $[\mathrm{n}]_{\mathrm{o}}$ one shall be deprived of his life intentionally save in the execution of a sentence of a court following his conviction of a crime for which this penalty is provided by law' (emphasis added). Article 2(2) ECHR then provides a further exception to the prohibition of intentional killing:

Deprivation of life shall not be regarded as inflicted in contravention of this Article when it results from the use of force which is no more than absolutely necessary:

(a) in defence of any person from unlawful violence;

(b) in order to effect a lawful arrest or to prevent the escape of a person lawfully detained;

(c) in action lawfully taken for the purpose of quelling a riot or insurrection.

17 See Minutes of the 14th Session of Committee I, 17 November 1969, in T. Buergenthal and R. Norris (eds), Human Rights: The Inter-American System, Part 2: The Legislative History of the American Convention on Human Rights (1982), at 131, 136-137. 
An intentional killing of a person by a state would thus be lawful only if it was absolutely necessary for achieving one of the three specified aims, which are a numerus clausus. This is a significantly stricter standard than that of arbitrariness in the ICCPR and the ACHR, ${ }^{18}$ and indeed the ECHR's drafters wanted to avoid the ambiguity and the possibility of abuse that an arbitrariness standard would bring. On the other hand, this explains why they made Article 2 derogable in times of war, since status-based targeting could not on its face fit any of the Article 2(2) exceptions, whereas the arbitrariness standard in the other treaties leaves ample room for harmonious interpretation in accordance with the relevant rules of IHL.

We can observe the same difference in drafting technique with respect to the liberty of person. While Article 9(1) ICCPR prohibits 'arbitrary arrest or detention' and Article 7(3) ACHR prohibits 'arbitrary arrest or imprisonment', Article 5(1) ECHR again sets out a closed list of six grounds for detention, which exclude the possibility of preventive security detention, ${ }^{19}$ but the right is derogable in the ECHR as well as in the other treaties. All three, however, require judicial control of detention in very similar terms. ${ }^{20}$

Finally, the third paragraphs of the derogation clauses require derogating states to inform the other states parties, through the UN Secretary-General (Article 4(3) ICCPR) or the Secretary General of the Organization of American States (Article 27(3) ACHR), or the Secretary General of the Council of Europe (Article 5(3) ECHR), of the provisions from which the derogation is made, the reasons for the derogation, and the termination of the derogation. This is an essentially procedural requirement of international supervision.

Bearing in mind the texts of the three treaties we can now proceed to look at several specific interpretative problems that will be addressed in turn: firstly, whether we should assign any importance to the absence of an explicit reference to 'war' in Article 4(1) ICCPR, and, secondly, how we should interpret that reference in the other two treaties; thirdly, whether derogations require a formal public act or can take effect automatically; and, finally, the meaning of the 'life of the nation' standard in the ICCPR and the ECHR, and specifically whether it precludes extraterritorial derogations.

\section{B. No 'War' in the ICCPR}

The explicit reference to 'war' in Article 15 ECHR and Article 27 ACHR is the best possible evidence that the treaties' drafters intended them to apply in times of

\footnotetext{
18 Note that despite the textual differences the Human Rights Committee and the Inter-American Court have interpreted the arbitrariness standard in the right to life context as strictly as the ECHR's absolute necessity standard, at least in peacetime conditions.

19 See ECtHR, Al-Jedda v. United Kingdom, Appl. no. 27021/08, Judgment of 7 July 2011, para. 100: 'It has long been established that the list of grounds of permissible detention in Article 5 $\$ 1$ does not include internment or preventive detention where there is no intention to bring criminal charges within a reasonable time.'

20 See Art. 9(4) ICCPR, Art. 5(4) ECHR, Art. 7(6) ACHR.
} 
armed conflict. ${ }^{21}$ But should we a contrario construe the absence of an explicit reference to 'war' in Article 4 ICCPR as evidence that the drafters of that treaty did not intend armed conflict to fall under the umbrella concept of a public emergency threatening the life of the nation?

Such an inference would be entirely unwarranted. The drafting history of the Covenant is replete with references to war as the paradigmatic example of a public emergency justifying a derogation, and indeed the initial drafts of Article 4 expressly mentioned war, much like the ECHR and the ACHR. ${ }^{22}$ The explicit reference to war was dropped from the final text of Article 4 not because the drafters believed that the ICCPR was completely inapplicable to wartime situations, or because they thought that wartime situations do not justify derogations. ${ }^{23}$ Rather, ' $[w]$ hile it was recognized that one of the most important public emergencies was the outbreak of war, it was felt that the covenant should not envisage, even by implication, the possibility of war, as the United Nations was established with the object of preventing war'. ${ }^{24}$

During the drafting of the derogation clause, ${ }^{25}$ the United Kingdom, which had initially proposed the inclusion of 'war' in the clause, also proposed wording that would allow derogations from the right to life in respect of deaths resulting from lawful acts of war', 26 the same wording we find today in Article 15(2) ECHR, also on the basis of the UK proposal. ${ }^{27}$ To just get a flavour of the debates, this was objected to by the Soviet delegate on the grounds that such an expansive reference to the possibility of war 'would seem sheer mockery to the peoples of the world' ${ }^{28}$ The UK delegate, for her part, 'protested against the suggestion that she favoured

21 See also Art. 72 of Protocol Additional to the Geneva Conventions of 12 August 1949, and relating to the Protection of Victims of International Armed Conflicts (Protocol I), 8 June 1977, which refers to 'other applicable rules of international law relating to the protection of fundamental human rights during international armed conflict', as well as the second preambular paragraph of Protocol Additional to the Geneva Conventions of 12 August 1949, and relating to the Protection of Victims of Non-International Armed Conflicts (Protocol II), 8 June 1977, referring to 'international instruments relating to human rights [that] offer a basic protection to the human person'.

22 See generally M. Bossuyt, Guide to the 'Travaux Préparatoires' of the International Covenant on Civil and Political Rights (1987) at 81-87.

23 See also Buergenthal, supra note 15, at 79; Higgins, supra note 1, at 286-287; Y. Dinstein, The International Law of Belligerent Occupation (2009), at 72.

24 Bossuyt, supra note 22, at 86.

25 For a detailed account see Svensson-McCarthy, supra note 1, at $199 \mathrm{ff}$.

26 See Commission of Human Rights, 5th Session, Summary Record of the 195th Meeting, UN Doc. E/CN.4/SR 126, 17 June 1949, at 5.

27 See Nowak, supra note 1, 88-89. Generally on the UK government's involvement and the motivations of its various officials in the drafting of the ICCPR and the ECHR, and of their derogation clauses in particular, as well as on the first cases involving the United Kingdom's resort to derogations in its then still extant colonial empire, see B. Simpson, Human Rights and the End of Empire (2004), especially at $874 \mathrm{ff}$.

28 UN Doc. E/CN.4/SR 126, supra note 26, at 6. At the same meeting, the Soviet delegate was not however opposed to the inclusion of the reference to war as such in Art. 4(1), but proposed that the words 'directed against the interests of the people' should be inserted after the words 'In time of war or other public emergency'. That was a most important limitation clause, designed to limit derogations from human rights to cases where the interests of the people were at stake. Thus it would be made clear that that was the 'exclusive purpose of the limitation, which must only be put into effect as a measure of defence against aggression and other acts of war directed against the interests of the people'. Ibid. 
war. It was because she hated and loathed war that she desired safeguards for human rights in the event of its occurrence. ${ }^{29}$ During much of the drafting this diplomatic rigmarole continued, with some states arguing that the inclusion of war in the derogation clause was useful, and other claiming that doing so would undermine the UN's basic mission to outlaw the recourse to war, or would be potentially problematic for some other reason. Yet, even so, most states expressly agreed that wars may very well happen in the future and that a derogation clause would substantively cover such situations, regardless of the language used. ${ }^{30}$

A few states doubted the wisdom of having a derogation clause altogether. This was, for instance, the view of the United States, whose opposition to a derogation clause stemmed in part from the view that the limitation clauses in the various specific articles of the Covenant 'made adequate allowance for cases of war or public emergency'. ${ }^{31}$ The Philippines, on the other hand, 'considered it useless to envisage the possibility of war in the Covenant, for if a war were to break out, conventions on the rules of war would take precedence over all other international instruments'. ${ }^{32}$ The United States later added that 'it was unfortunately necessary to take the threat of war or other serious situations into account and that was the reason for the provisions of article 4.33

The reference to war was removed from Article 4 ICCPR at the Commission's session of 16 May 1950, when a French proposal, which allowed derogation in a 'state of emergency officially proclaimed by the authorities or in the case of public disaster', ${ }^{34}$ replaced the original UK-proposed text. ${ }^{35}$ The stated purpose of the French amendment was 'to prevent states from derogating arbitrarily from their obligations under the covenant when such an action was not warranted by events' ${ }^{36}$ Again, France at no point argued that wartime situations would be excluded. The

29 Ibid., at 9.

30 Thus, the French delegate for his part noted that the concept of an emergency justifying a derogation should not be limited to war. Ibid., at 8 . The Indian delegate noted that the reference to a public emergency might enable the word 'war' to be avoided, while the Chinese delegate thought that war should not be mentioned because 'to mention war as a condition permitting derogation of certain human rights would involve recognition of the concept of rules of war, which he deemed questionable, at the very least'. Ibid., at 8-9. Australia argued that the 'Commission [on Human Rights] should be practical and reasonable enough to see that the Covenant must provide for the possibility of a war'. Commission of Human Rights, 5th Session, Summary Record of the 127th Meeting, UN Doc. E/CN.4/SR.127, 17 June 1949, at 4. The Guatemalan delegate expressed similar views (ibid.), as did Egypt (ibid., at 6). France then objected to the inclusion of the word 'war', but again without arguing that the concept of an emergency should exclude situations of war. Ibid., at 8. At later stages of the drafting, Yugoslavia proposed that the word 'defensive' should be inserted before the word 'war', see UN Doc. E/CN.4/SR.195, supra note 16, at 9.

31 See UN Doc. E/CN.4/SR.127, supra note 30, at $3 . \quad 32$ Ibid., at 5.

33 See UN Doc. E/CN.4/SR.195, supra note 16, at 10. See also the views of the delegate of Chile, ibid., at 13, para. 63 (proposing the deletion of Art. 4 because it was open to abuse, while other provisions of the Covenant 'sufficiently covered all cases which might arise in time of war').

34 See Commission of Human Rights, 6th Session, Provisional Agenda, UN Doc. E/CN.4/356, 22 March 1950, at 19.

35 See UN Doc. E/CN.4/SR.195, supra note 16, at 18, para. 97. The French amendment was adopted by six votes to three, with four abstentions.

36 Ibid., at 16 , para. 82 . 
British proposal to allow for derogations from the right to life in respect of deaths arising from lawful acts of war was then narrowly defeated, with the French delegate arguing that the amendment was necessary since such acts would not violate the right to life, which clearly covered cases of self-defence. ${ }^{37}$

Two years later, the drafting of the Covenant was nearing its end within the Commission. After the adoption of the ECHR, ${ }^{38}$ the United Kingdom tried to reverse the changes brought about by the French amendment. It again tried to include a reference to war in the first paragraph and to the possibility to derogate from the right to life in war in the second paragraph of the derogation clause. ${ }^{39}$ Both of these points were met with significant opposition and the United Kingdom withdrew its amendment. However, the United Kingdom was successful in aligning the text of Article 4(1) ICCPR with that of Article 15(1) ECHR, so that it now referred to public emergencies threatening the life of the nation, with the addition of the official proclamation requirement from the French amendment. The reason again given by states for opposing the reinsertion of the reference to war into the derogation clause was not that they thought that the clause would not apply to wartime situations, but that they wanted to avoid the implication that a UN treaty would endorse continued resort to war in international relations. ${ }^{40}$

In sum, the drafting history of the ICCPR is (on this matter at least) perfectly clear; the Article 4 derogation clause was meant to apply to situations of war, however these were defined. ${ }^{41}$ The absence of an express reference to war cannot be

37 Ibid., at 21, paras 128-130. The UK amendment failed as there were four votes in favour, four against and five abstentions.

38 The travaux of the ECHR are generally even less helpful that those of the ICCPR, as the various interpretative difficulties regarding Art. 15 were never really discussed systematically, or at least such discussions were not recorded. For brief overviews of the drafting, see Secretariat of the European Commission, Preparatory Work on Article 15 ECHR, 22 May 1956, available online at http://www. echr.coe.int/LibraryDocs/Travaux/ECHRTravaux-ART15-DH\%2856\%294-EN1675477.pdf (last accessed 23 July 2015); St. J. Macdonald, 'Derogations under Article 15 of the European Convention on Human Rights', 36 Columbia Journal of Transnational Law (1997) 225, at 225-233.

39 See UN Doc. E/CN.4/L.139.

40 For instance, the delegate of Chile stated that 'it would be inappropriate in an international covenant to include a reference to war. Moreover, from a strictly legal point of view such a reference was unnecessary because public emergency would be deemed to cover a time of war'. Commission of Human Rights, 8th Session, Summary Record of the 313th Meeting, UN Doc. E/CN.4/SR.330, 1 July 1952, at 4. Uruguay believed that a reference to 'war' would be acceptable only if it was specified that the war was recognized only in self-defence or was otherwise compliant with the UN Charter. Ibid., at 5. The United States representative similarly considered that 'the reference to war in paragraph 1 was unnecessary in view of the inclusion of the words "public emergency" and added that in an international covenant it would be regrettable to include any allusion to war'. Ibid., at 5 . The Soviet Union was now opposed in principle to any reference to war, but argued that the concept of a public emergency was broad enough. Ibid, at 6-7. The French representative insisted on the official proclamation requirement, and felt that the existing wording of the clause 'would cover war and added that from the legal and psychological point of view a direct reference to war was undesirable'. Ibid., at 7. The Belgian delegate claimed that in the case of war the covenant would be at least suspended between belligerents (and was the only delegate to say so). Ibid., at 7. The Egyptian representative agreed that an explicit reference to war was undesirable. Ibid., at 8 .

41 See also Svensson-McCarthy, supra note 1, at 214; Nowak, supra note 1, at 89-90; McGoldrick, 'The Interface between Public Emergency Powers and International Law', 2 International Journal of Constitutional Law (2004) 380, at 393. 
taken as suggesting that the ICCPR cannot apply in wartime, or that it is somehow completely displaced by the law of war. But, having said so, what are we to make of the references to 'war' in the ECHR and the ACHR? And specifically, what are we to make of the possibility to derogate from the right to life under the ECHR, which is, as we have seen, unique to that treaty?

\section{C. 'War' in the ECHR, the ACHR and the Modern Law of Armed Conflict}

A major problem with the references to 'war' in the ECHR and the ACHR is that the legal concept of war has fallen into disuse in modern international law. Starting from the adoption of the UN Charter and the 1949 Geneva Conventions, international law has drawn a (relatively) firm distinction between the jus ad bellum and the jus in bello, ${ }^{42}$ and replaced 'war' in both settings with different concepts. In the ad bellum arena we now employ concepts such as a use of force or an armed attack. ${ }^{43}$ In the jus in bello, the Geneva Conventions introduced two new thresholds for their own application: IAC in Common Article 2, and NIAC in Common Article 3 of the Conventions. In a gradual process which entailed the evolution of custom as well as the adoption of new treaties such as the 1977 Additional Protocols to the Conventions, the IAC and NIAC concepts became thresholds for the application of the whole of the law of armed conflict, or IHL, not merely the Conventions themselves. ${ }^{44}$ The main reason for discarding 'war' was that it was a concept that was considered to be too subjective, rigid and technical—many wars in the material sense were historically fought but did not qualify as war in the technical, formal legal sense, thus depriving those affected by them of legal protection. 'War' also produced consequences across the board in the legal relations between the belligerents, moving them from the law of peace into the law of war and abrogating or suspending all peacetime treaties between them. IAC and NIAC were thus devised as - or rather grew to become - thresholds which are as objective and factual as possible, and produce consequences mainly at the level of the law of armed conflict.

Hence, when we look at the references to 'war' in the ECHR and the ACHR, as well as at the introduction and the removal of the concept from the text of the ICCPR, we must appreciate that the general framework of war and peace was very much in flux at the time the treaties were drafted. It is true that the 1949 Geneva Conventions were adopted before the human rights treaties, but their IAC and NIAC thresholds had not yet penetrated the whole of the law of war, as it was then

\footnotetext{
42 For a strong defense of the separation between the jus ad bellum and the jus in bello, and the concomitant principle of equal application of the jus in bello to all parties to a conflict, see Sloane, 'The Cost of Conflation: Preserving the Dualism of Jus ad Bellum and Jus in Bello in the Contemporary Law of War', 34 Yale Journal of International Law (2009) 47.

43 See further Kritsiotis, 'Topographies of Force', in M. Schmitt and J. Pejic (eds), International Law and Armed Conflict: Exploring the Faultlines: Essays in Honour of Yoram Dinstein (2007) 29.

44 See further Milanovic and Hadzi-Vidanovic, supra note 8, at 258-269, and the sources cited therein.
} 
understood. The drafters were, inevitably, partly influenced by the classical position, which rigidly distinguished between war and peace, while the new one was yet to solidify. Examinations of the text and the drafting history are thus inevitably somewhat anachronistic.

Bearing this in mind, there are three possible ways in which the word 'war' in the ECHR and the ACHR can be interpreted:

(1) As a reference to the technical legal concept of 'war' as it existed in classical international law; 45

(2) As a reference to the modern concept of IAC, which is like 'war' inter-state in nature but is objective and factual, and was indeed meant as a replacement for 'war', ${ }^{46}$ with perhaps the addition of belligerent occupation as a subspecies of IAC;

(3) As a reference to any type of armed conflict regulated by contemporary IHL, thus including both IAC and NIAC, as well as occupation and possibly any third type of armed conflict if it ever evolves through custom or is created by treaty.

When a treaty refers to a legal concept without defining it, and the meaning of that concept evolves over time, we normally have recourse to the general rules of treaty interpretation to establish whether the concept as set out in the treaty should be allowed to evolve or should be applied as it stood at the time the treaty was adopted. ${ }^{47}$ But the general rules on treaty interpretation do not exclude any of these three options, nor is the drafting history of the treaties of any help at all in determining whether the reference to 'war' was meant to evolve with the current state of the law of armed conflict, or not.

The choice between these three options is hence really up to the interpreter, and will depend on a policy assessment of the consequences each option would produce. The consequence of option (1) would be that derogations could hardly ever be applied on the grounds of war alone, since war in the formal, classical sense is exceptionally rare today. Option (2) would have the benefit of clarity due to the factual nature of the IAC threshold and alignment with contemporary IHL, but it would exclude the vast majority of contemporary conflicts, which are NIACs. Option (3) would hence allow for the most expansive recourse to derogations.

This choice is only of limited relevance in interpreting the reference to 'war' in Article 15(1) ECHR and Article 27(1) ACHR, since even if we opt for the most restrictive interpretation of 'war', IACs and NIACs could still comfortably qualify as some 'other public emergency threatening the life of the nation' or a 'public

45 See, e.g. Fitzpatrick, supra note 1 , at 57-58.

46 See, e.g. Norris and Desio Reiton, supra note 14, at 195 (arguing that the definition was meant to cover the classical concept of (inter-state) war which would exclude civil conflicts, but that it 'does not necessarily exclude the more modern concept of an international armed conflict'). See also Ergec, supra note 1 , at $123 \mathrm{ff}$.

47 See, e.g. Institut de Droit International, Resolution on the Intertemporal Problem in Public International Law, 11 August 1975, para. 4. 
danger, or other emergency that threatens the independence or security of a State Party,' respectively. But the choice between the three alternatives is absolutely crucial for interpreting Article 15(2) ECHR, which allows derogations from the right to life 'in respect of deaths resulting from lawful acts of war'. Thus, while option (2) would allow for status-based targeting in IACs under the relevant rules of IHL, without option (3) status-based targeting in NIACs would (at least on the face of it) be more problematic, since in the absence of a derogation the applicable standard would be Article 2(2) ECHR, which requires the use of force to be 'no more than absolutely necessary' for the three aims it set out, one of which is 'quelling a riot or insurrection'. ${ }^{48}$

Note that because of the absence of any reference to 'war' in Article 4(1) ICCPR, a derogation from the ICCPR would need to satisfy the 'public emergency which threatens the life of the nation' test. ${ }^{49}$ Depending on how strictly we interpret the 'life of the nation' standard, one may very well argue that not all armed conflicts would necessarily satisfy that test, ${ }^{50}$ for instance in the case of a NIAC which is very localized or an IAC that is limited in the duration and intensity of hostilities, ${ }^{51}$ as, for example, with the relatively bloodless occupation of Crimea by Russia in February and March 2014. Similarly, satisfying an IHL qualification exercise and the 'war' criterion in Article 15(1) ECHR or Article 27(1) ACHR, might not dispense with the need to establish that the 'war' is sufficiently serious to justify a derogation. ${ }^{52}$ In other words, the issue would be whether war is merely listed as an example of a public emergency threatening the life of the nation/public danger, or other emergency that threatens the independence or security of a state party, or is an independent justification for a derogation in its own right.

\section{D. 'Life of the Nation'}

Recall how in Al-Jedda Lord Bingham expressed doubts that an extraterritorial situation, in which a state had put itself voluntarily and from which it could withdraw, could ever satisfy the 'life of the nation' test in Article 15 ECHR. ${ }^{53}$ Lord Bingham's doubts were later echoed in two cases before the UK Supreme Court dealing with the ECHR rights of British soldiers deployed in Iraq vis-à-vis the United Kingdom, both confusingly called Smith. In the first case, Lord Philips briefly noted that the United Kingdom did not derogate with regard to the events in Iraq, and that 'troops were deployed abroad in circumstances falling short of

48 See also N. Melzer, Targeted Killing in International Law (2008), at 122.

49 See General Comment No. 29 States of Emergency (Art. 4), supra note 15, para. 3: 'The Covenant requires that even during an armed conflict measures derogating from the Covenant are allowed only if and to the extent that the situation constitutes a threat to the life of the nation.' See also Nowak, supra note 1, at 90.

50 See, e.g. Svensson-McCarthy, supra note 1, at 214.

51 See Moir, supra note 15, at 183.

52 See, e.g. Norris and Desio Reiton, supra note 14, at 194 (arguing that this is the correct position under both the ECHR and the ACHR).

53 See supra note 4 and accompanying text. 
those permitting derogation under article $15 .{ }^{54}$ In the second case, Lord Hope, joined by three other justices, remarked that:

$[T]$ he phrase 'threatening the life of the nation' suggests that the power to derogate under this article is available only in an exceptional situation of crisis or emergency which affects the whole population and constitutes a threat to the organised life of the community of which the state is composed: Lawless v Ireland (No. 3) (1961) 1 EHRR 15, para 28.... [discusses Lord Bingham's views in Al-Jedda] I do not think therefore that it would be right to assume that concern about the practical consequences in situations such as those with which we are dealing in this case can be answered by exercising the power to derogate. The circumstances in which that power can properly be exercised are far removed from those where operations are undertaken overseas with a view to eliminating or controlling threats to the nation's security. The jurisprudence of the Strasbourg court shows that there are other ways in which such concerns may be met. ${ }^{55}$

The concerns Lord Hope referred to were the potentially excessive rigidity of Article 2 ECHR positive obligations if they are applied to military deployments overseas, which is why one of the interveners invoked the possibility of derogations as a means of introducing needed flexibility. Lord Hope rightly observed that such concerns could be accommodated even without derogations, since the due diligence positive obligations are inherently flexible and also leave ample room for the state's margin of appreciation. ${ }^{56}$

However, the same cannot be said of the negative obligation under Article 2 to refrain from intentionally taking human life unless it is absolutely necessary to do so, and it is there that the full impact of a derogation in respect of deaths result from lawful acts of war' might be felt, both with regard to the targeting itself and to permitting a degree of collateral damage in accordance with an IHL proportionality analysis. The ECtHR's case-law has been much less flexible when it comes to the actual killing of individuals by a state, rather than the state's obligation to protect individuals from harm or investigate deaths. ${ }^{57}$

Lord Hope's holding that circumstances in which derogations would be appropriate 'are far removed from those where operations are undertaken overseas with a view to eliminating or controlling threats to the nation's security' is at best an overstatement. It is true that there are plenty of authorities, like the ECtHR's judgment in Lawless, that at first glance seem to set a threshold for derogation very high: 'the natural and customary meaning of the words "other public emergency threatening the life of the nation" is sufficiently clear... they refer to an exceptional situation of crisis or emergency which affects the whole population and constitutes

${ }^{54} R$ (Smith) $v$. Secretary of State for Defence [2010] UKSC 29, para. 57.

$55 R$ (Smith and others) $v$. The Ministry of Defence [2013] UKSC 41, paras 59-60.

56 Ibid., para. 61

57 But see ECtHR, Finogenov and Others v. Russia, Appl. nos. 18299/03 and 27311/03, Judgment of 20 December 2011, dealing with the hostage-taking in the Dubrovka theatre in Moscow, in which the Court found that the use of an anaesthetic gas in the theatre by Russian authorities, which also led to the deaths of a number of hostages, did not in itself amount to a violation of Art. 2 ECHR. In effect, the Court allowed for the possibility of collateral damage under human rights law. 
a threat to the organised life of the community of which the State is composed'. ${ }^{58}$ But let us also look at the facts on which the ECtHR found the life of the nation to have been threatened: 'in the first place, the existence in the territory of the Republic of Ireland of a secret army engaged in unconstitutional activities and using violence to attain its purposes; secondly, the fact that this army was also operating outside the territory of the State, thus seriously jeopardizing the relations of the Republic of Ireland with its neighbour; and thirdly, the steady and alarming increase in terrorist activities from the autumn of 1956 and throughout the first half of 1957'.59 The terrorist activities took place both in Northern Ireland, i.e. the United Kingdom, and within the Republic of Ireland itself, and involved a number of armed attacks, mostly with explosives, against property and infrastructure. The most serious attack was an IRA ambush against a police patrol, during which one policeman was ambushed and one injured. ${ }^{60}$

This, then, was a threat to the life of the nation that was found sufficient for a derogation in Lawless. It was on any reasonable appraisal quite real, but far from existential. The same goes for IRA activities within the United Kingdom, which were also found to justify a derogation. ${ }^{61}$ The Human Rights Committee has also been reluctant to directly challenge arguable state determinations of the existence of a public emergency, merely urging, for example, the United Kingdom in 1995 to keep the issue under review and consider the appropriateness of withdrawing the derogation in respect of Northern Ireland due to the diminution of violence there. ${ }^{62}$ Similarly, both the House of Lords and the ECtHR accepted the UK government's view that an emergency threatening the life of the nation existed for the United Kingdom after Al-Qaeda's 9/11 attacks, even though no attack had at the time taken place on British soil. ${ }^{63}$ The Court explicitly said that it was prepared to look at a broad range of factors in establishing whether an emergency exists, and that the emergency need not be so severe as to imperil the state's institutions and the existence of a civil community. ${ }^{64}$ The Court has also been ready to accept an emergency which was localized to a part of a state's territory only; in other words, it did not directly affect the whole of its population, or the 'nation' as such. ${ }^{65}$

It must be said that the vast majority of very genuine emergencies in which courts or human rights bodies accepted that a derogation was justified pale in

58 ECtHR, Lawless v. Ireland (No. 3), Appl. no. 332/57, Judgment of 1 July 1961, section on 'The Law', para. 28

59 Ibid.

60 Ibid., section on 'The Facts', para. 14, and section on 'The Law', para. 29.

61 ECtHR, Ireland v. United Kingdom, Appl. no. 5310/71, Judgment of 18 January 1978, para. 205.

62 See Concluding Observations of the Human Rights Committee on the United Kingdom, UN Doc. CCPR/C/79/Add.55, 27 July 1995, para. 23.

63 See ECtHR, $A$ and others $v$. United Kingdom, Appl. no. 3455/05, Judgment of 19 February 2009 (Grand Chamber), paras 177-181.

64 Ibid., para. 179.

65 See, e.g. ECtHR, Aksoy v. Turkey, Appl. no. 21987/93, Judgment of 18 December 1996, paras 70 and 84 (emergency existed in South-East Turkey, but incommunicado detention without recourse to judicial review was not strictly required by the exigencies of the situation); Ireland $v$. United Kingdom, supra note 61, paras 205, 212 (emergency in Northern Ireland). 
comparison to the horrors of Iraq (both during and after the formal end of occupation) and the brutality of the insurgency there. So why should a derogation not have been permitted? Even if we took the Lawless test at face value, all we would need to do to enable its application to UK activities in Iraq would be to adjust the very last part of the sentence: 'an exceptional situation of crisis or emergency which affects the whole population and constitutes a threat to the organised life of the community in which the Convention is applied'. In Serdar Mohammed Mr Justice Leggatt endorsed a similar approach:

Now that the Convention has been interpreted, however, as having such extraterritorial effect, it seems to me that Article 15 must be interpreted in a way which reflects this. It cannot be right to interpret jurisdiction under Article 1 as encompassing the exercise of power and control by a state on the territory of another state, as the European Court did in the Al-Skeini case, unless at the same time Article 15 is interpreted in a way which is consonant with that position and permits derogation to the extent that it is strictly required by the exigencies of the situation. [... ] Article 15, like other provisions of the Convention, can and it seems to me must be 'tailored' to such extraterritorial jurisdiction. This can readily be achieved without any undue violence to the language of Article 15 by interpreting the phrase 'war or other public emergency threatening the life of the nation' as including, in the context of an international peacekeeping operation, a war or other emergency threatening the life of the nation on whose territory the relevant acts take place. ${ }^{66}$

In other words, if we accept that the human rights treaty can apply outside a state's own territory, and not just in very limited circumstances, then the mere fact of extraterritoriality does not seem to be an adequate reason to categorically ban recourse to derogations. ${ }^{67}$

One potential solution for the extraterritoriality problem is for the state acting outside its territory to be able to rely on any derogation by the territorial state. But to my eyes this approach would not be sound either conceptually or practically. At the conceptual level, it is the state whose obligations are at issue that needs to derogate if it wishes to diminish the scope of its own obligations. And that state and the territorial state may not even be bound by the same treaty-for instance, although the United Kingdom is a party to both the ECHR and the ICCPR, Afghanistan and Iraq are parties to the ICCPR but not to the ECHR, and it is precisely with regard to the ECHR's more rigid standards on the deprivation of life and liberty that a derogation might be needed. At a purely practical level, I fail to see why an intervening state should be at the mercy of the territorial state's choice as to whether to derogate. Note that even though Iraq had ratified the ICCPR as early as in 1971, and Afghanistan had acceded to it in 1983, neither of these states ever

66 Serdar Mohammed v. Ministry of Defence [2014] EWHC 1369 (QB), paras 155-156.

67 See also Sassòli, 'The Role of Human Rights and International Humanitarian Law in New Types of Armed Conflicts', in O. Ben-Naftali (ed.), International Humanitarian Law and International Human Rights Law (2011) 34, at 66: '[O]ne cannot simultaneously hold a state accountable because it has a certain level of control abroad and deny it the possibility to derogate because there is no emergency on that state's own territory. An emergency on an occupied territory or a territory where the state has a certain limited control must be sufficient;...'. K. Mujezinovic Larsen, The Human Rights Treaty Obligations of Peacekeepers (2012), at 308-309; Sari, supra note 6, para. 16. 
derogated despite all the unfortunate events they went through, tragedies of such magnitude and scale that they surpass most other situations in which other states had derogated. ${ }^{68}$ This is not to say that that any derogation by the territorial state would be completely irrelevant-they could serve as evidence that a genuine emergency existed as a matter of fact, and as to what measures were strictly required by the exigencies of the situation.

Lord Bingham also pointed out in Al-Jedda that Article 15 ECHR should be inapplicable because the state voluntarily embarked on an overseas military operation, from which it could withdraw. But this argument also fails to persuade. ${ }^{69}$ After all, Ireland and the United Kingdom could also have given in to the IRA's demands and thus had averted or mitigated the public emergency. And so could any other state that derogated due to an internal problem.

In sum, if we accept that the 'life of the nation' test does not require a truly existential threat to a state, and that it can be applied even to localized emergencies within the state, ${ }^{70}$ then I do not see why it could also not be applied to localized emergencies outside the state, if the human rights treaties themselves apply. ${ }^{71}$ And while it did not directly address the issue in Al-Jedda, the ECtHR did note the UK failure to derogate, thus implying that it did not think that extraterritorial derogations would be categorically impermissible. ${ }^{72}$

Of course, derogation measures would still need to be strictly required by the exigencies of the situation. If we again take the United Kingdom and Iraq as an example, such measures would be justifiable only to the extent that they related to Iraq. In other words, that a real emergency existed in the parts of Iraq in which British troops were deployed, which could for instance have justified the preventive security detention of an insurgent detained in UK military operations, does not mean that the same measures could have been used in the United Kingdom itself where no such emergency existed.

Perhaps there is some other reason to categorically prohibit extraterritorial derogations, but such a prohibition does not formally flow from the text or the

68 Status of ratifications and notifications of derogation available online at the UN Treaty Collection website at https://treaties.un.org/Pages/ViewDetails.aspx?src=TREATY\&mtdsg_no=IV-4\&chap ter $=4 \&$ lang=en (last accessed 23 July 2015).

69 I set aside for the moment the issue of the intervention's legality under other rules of international law, to which I will turn later in this chapter-see Section 4 infra.

70 See, e.g. Buergenthal, supra note 15, at 80; Macdonald, supra note 38, at 239-241; El Zeidy, 'The ECHR and States of Emergency: Article 15-A Domestic Power of Derogation from Human Rights Obligations', 4 San Diego International Law Journal (2003) 277, at 284-285; Mujezinovic Larsen, supra note 67, at 310.

71 See Dinstein, supra note 23, at 73 (arguing that the rationale for localized emergencies 'applies even more vigorously to occupied territories (as completely separate entities) than to parts of the territory of a Belligerent Party'). See also Ergec, supra note 1, at 129 (arguing that 'l'Etat occupant doit par conséquent répondre, sur le terrain de l'article 15 , de toute mesure dérogatoire qu'il serait amené à imposer dans le territoire occupé' [The occupying state shall therefore be responsible, under Article 15, for any derogation measure which it will bring about in the occupied territory]).

72 Al-Jedda v. United Kingdom, supra note 19, para. 100. See also ECtHR, Georgia v. Russia (II), Appl. no. 38263/08, Decision of 13 December 2011, para. 73 (noting that neither Georgia nor Russia made a derogation in the context of their 2008 conflict, which entirely took place on Georgian territory). 
treaties, their travaux or subsequent practice. ${ }^{73}$ The only plausible policy argument in that regard is that the state acting extraterritorially has no business-or has no right-to determine that an emergency exists in a territory over which it exercises no sovereign authority, or to take derogating measures. That argument partly turns on the issue of the legality of the extraterritorial state's intervention under other rules of international law, to which I will turn in Section 4. As I will explain, that question - whether, for example, the United Kingdom had any right to resort to derogations because it had unlawfully invaded Iraq in 2003-poses a serious dilemma. However that question is answered, one possible way of taking the peculiar nature of extraterritorial derogations into account would be to review the decision to derogate and the measures implemented by the state somewhat less deferentially than when a state derogates in its own territory.

\section{E. Automaticity and Proclamation}

I do not wish to examine at length the various issues that may arise regarding the derogation procedure. These include, for instance, whether notifications of derogation need to be communicated immediately or whether the derogating state is permitted a grace period, or indeed what might be the consequences of a failure to notify, namely whether it results in the nullity of the derogation or is a mere procedural defect that may be taken into account in assessing whether a genuine emergency existed. ${ }^{74}$ For present purposes, it suffices to say that derogations cannot be automatic, in the sense that a human rights treaty is derogated from whenever a particular emergency arises as a matter of fact, including situations of IAC and NIAC. Nor can derogations simply be effected by resort to measures that would otherwise violate the treaty, such as security detention. Rather, derogations always remain the choice of the relevant state and that choice must be made formally by some public act, regardless of any notification of derogation to the other states parties. Thus, for instance, while in one of the Cyprus/Turkey inter-state cases the European Commission did not want to take a position on what sanctions should follow from Turkey's failure to notify any derogation with respect to northern Cyprus, it held that:

Art. 15 requires some formal and public act of derogation, such as a declaration of martial law or state of emergency, and that, where no such act has been proclaimed by the High Contracting Party concerned, although it was not in the circumstances prevented from

73 And, as we have seen, the more permissive text of Art. 27(1) ACHR does not seem to pose any problem for extraterritorial derogation.

${ }^{74}$ For example, while Art. 4(3) ICCPR requires derogating states to 'immediately' inform the other states parties of the derogation and the reasons therefor, Art. 15 ECHR does not use the same language, and the ECtHR in Lawless, supra note 58, para. 47, did not consider a derogation communicated by Ireland 12 days after the derogation measures took effect to have been made with undue delay. See further Higgins, supra note 1, at 290-296; Harris et al., supra note 1, at 640-641. One could certainly imagine situations of dire emergency which can disrupt the normal functioning of a government, e.g. a surprise attack on its capital, that would justify delays in notifying derogations. Cf. Roxstrom et al., supra note 6, at 119-120. 
doing so, Art. 15 cannot apply.... The Commission, by twelve votes against three votes, concludes as regards the present case that it cannot, in the absence of some formal and public act of derogation by Turkey, apply Art. 15 of the Convention to measures taken by Turkey with regard to persons or property in the north of Cyprus. ${ }^{75}$

Notably, the Commission implicitly accepted the possibility of extraterritorial derogation, in other words that Turkey could have potentially derogated due to war or public emergency in Cyprus. Dissenting from the Commission's finding that a formal act of derogation was required, two of its members considered that the concurrent applicability of IHL in effect created an automatic derogation: ' $[\mathrm{M}]$ easures which are in themselves contrary to a provision of the European Convention but which are taken legitimately under the international law applicable to an armed conflict, are to be considered as legitimate measures of derogation from the obligations flowing from the Convention. ${ }^{.76}$

The automaticity approach is, in my view, seriously flawed in the derogation context. Note that the applicability of IHL in both IAC and NIAC is automatic, in the sense that the application of IHL is triggered as soon as a certain objective factual threshold is reached, regardless of whether the relevant parties recognize the existence of an armed conflict. But the same is not true of derogation measures under human rights treaties, which remain the choice of the state, subject to certain conditions. Any automaticity would remove the voluntary nature of the act of derogation and elide the distinction between violations of a human rights treaty and measures derogating from it. If the Article 15(2) ECHR reference to deaths resulting from lawful acts of war operated automatically, by mere fact of killing in wartime without any formal act of derogation, it would have been included in the list of exceptions in Article 2(2) ECHR rather than in the provision on derogation. ${ }^{77}$ Automaticity would be especially difficult to square with those situations, particularly NIACs, in which the relevant states deny the existence of an armed conflict, as with the United Kingdom in Northern Ireland or Russia in Chechnya, but an armed conflict did exist as a matter of fact, as was undoubtedly the case in Chechnya. In other words, IHL did automatically apply to the NIAC in Chechnya, regardless of what the Russian government said on the matter-thus, for example, a direct attack on Chechen civilians would have constituted a war crime. But the ECHR was not automatically derogated from in the sense of Article 15 merely because a NIAC objectively existed. ${ }^{78}$ Formality is a key safeguard for the interests of the people

75 Cyprus v. Turkey, Appl. nos. 6780/74 and 6950/75, Commission Report of 10 July 1976, at paras $527-528$.

76 Ibid., Dissenting Opinion of Mr. G. Sperduti, Joined by Mr. S. Trechsel, para. 7. See also Ergec, supra note 1 , at 305 .

77 See also E. Wicks, The Right to Life and Conflicting Interests (2010), at 82.

78 Cf. ECtHR, Isayeva v. Russia, Appl. no. 57950/00, Judgment of 24 February 2005, at para. 191 (noting that 'No martial law and no state of emergency has been declared in Chechnya, and no derogation has been made under Article 15 of the Convention (see $\S 133$ ). The operation in question therefore has to be judged against a normal legal background.'); Georgia v. Russia (II), supra note 72, para. 73 (noting that neither Georgia nor Russia made a derogation in the context of their 2008 conflict); McVeigh and Others v. United Kingdom, Appl. nos. 8022/77, 8025/77 and 8027/77, Commission Report of 18 March 1981, at 44, paras 155-156 (noting that while it had derogated 
living in the area and other individuals affected, as well as for the other states parties, and it entails the state taking public political responsibility for its decision. ${ }^{79}$ One could also wonder what automaticity would entail when the ECHR encountered areas of international law other than IHL. ${ }^{80}$ Recall also that Article 4(1) ICCPR requires the existence of public emergencies to be officially proclaimed, and that since all ECHR states parties are also parties to the ICCPR such proclamation is necessary in order for the derogation not to be inconsistent with the states' other obligations under international law. ${ }^{81}$

This is not to say that IHL would be irrelevant in the absence of a derogation. Even if IHL can prevail over inconsistent provisions of human rights treaties in times of armed conflict, this would be due to some higher-order principle such as lex specialis or due to the policy choice of the interpreter, not due to the effect of the derogation clauses. An automatic derogation is no derogation at all.

\section{F. Plausibility of Several Different Interpretations}

I hope to have shown in the preceding discussion that the text of Article 4(1) ICCPR and Article 15(1) ECHR, specifically the reference to the 'life of the nation,' does not present a categorical bar to extraterritorial derogations. ${ }^{82}$ Article 27(1) ACHR uses a different standard in any event. The question of extraterritorial derogation was not discussed during the drafting of the three treaties, and the purpose of the 'life of the nation' standard was to qualify the gravity and nature of the public emergency, not its geographical scope. The existing case-law on the 'life of the nation' standard has interpreted that standard relatively flexibly, and does not of itself stand in the way of extraterritorial derogations.

In sum, the derogation clauses are open to several reasonable interpretations. If states or courts do decide against extraterritorial derogations this should be not on the account of the (supposedly clear) text alone. ${ }^{83}$ This interpretative choice cannot be made solely by formal means, but on the basis of whether one believes, or not,

with respect to the situation in Northern Ireland the UK government did not seek to invoke Art. 15 ECHR with respect to arrests and detention of individuals in mainland Great Britain, and that accordingly Art. 15 was inapplicable).

79 See also Nowak, supra note 1, at 92: '[O]fficial proclamation is a conditio sine qua non ... it is to prevent de facto derogations, as well as subsequent attempts to justify human rights violations that have already been committed.'

80 See also Harris et al., supra note 1, at 640.

81 Cf. ECtHR, Brannigan and McBride v. United Kingdom, Appl. nos. 14553/89 and 14554/89, Judgment of 25 May 1993, at para. 73.

${ }^{82}$ See also Krieger, 'After Al-Jedda: Detention, Derogation, and an Enduring Dilemma', 50 Military Law and the Law of War Review (2011) 419, at 436: 'Although the wording of Article 15 para. I ECHR refers to the life of the nation seeking to derogate, it is not so strictly formulated that it could not allow for a more dynamic interpretation, so to include unstable foreign territories where the Member State in question would operate'; Wilde, 'The Extraterritorial Application of International Human Rights Law on Civil and Political Rights', in S. Sheeran and N. Rodley (eds), Routledge Handbook of International Human Rights Law (2014) 635, at 654-655.

83 See Sari, supra note 6, para. 19: "[T] he term "nation" in Article 15 should be construed as extending to any third States in which the armed forces of the contracting parties operate. While some have suggested that such a reading would constitute an exercise in "dynamic" treaty interpretation, it 
that extraterritorial derogations would be normatively desirable. ${ }^{84}$ In the context of armed conflict in particular, the desirability or the need for derogations is directly tied to how we conceptualize the relationship between human rights and IHL and the scope of the lex specialis principle. Historically, the great concern on the part of human rights bodies and scholars alike with respect to derogations was the possibility of their abuse as enablers of domestic repression. ${ }^{85}$ Today those concerns are no less relevant, but the issue of the relationship with IHL is relatively new and may call for a more expansive recourse to derogations. But let us first see what the options are.

\section{The Link to IHL}

Both the text and the travaux of the major human rights treaties support the proposition that they will continue applying during 'war' or armed conflict and as, we have seen, this is also the view of the ICJ and human rights bodies. But that is all that the text tells us, and the drafting history is equally of little help. If the question is what the treaties' drafters really intended with regard to their relationship with IHL, the simple answer is that we have no idea, assuming that the drafters did actually intend something.

For example, the ICCPR's travaux tell us virtually nothing about how the treaty would apply to concrete problems in military operations. We have one isolated statement by the Philippine delegate, as already quoted, to the effect that 'conventions on the rules of war would take precedence over all other international instruments', ${ }^{86}$ which is clearly rooted in the classical, hard distinction between the law of war and the law of peace. But other delegations expressed neither agreement nor disagreement with this statement, even though the general tenor of their discussion assumed the continued applicability of the ICCPR in wartime. No delegation during the entire drafting process ever mentioned the much-vaunted lex specialis principle. At another session, and again echoing the classical position, the Belgian delegate briefly said that the ICCPR would at the very least be suspended between belligerents in wartime. ${ }^{87}$ But two years earlier that very same Belgian representative questioned the inclusion of the prohibition of torture and other forms

may amount to nothing more than a contextual reading of the text in line with the general rule of interpretation laid down in Article 31(2) of the Vienna Convention on the Law of Treaties.'

${ }^{84}$ See also Mujezinovic Larsen, supra note 67, at 313 (arguing that 'resort to [extraterritorial] derogations in UN-mandated peace operations would be a clear advantage. It would create a coherent and transparent legal framework for the assessment of human rights obligations in such operations, it would allow troop contributing states to avoid obligations that it would be unrealistic to comply with, and it would in fact lead to an increased level of human rights protection in the area of deployment, since the scope of application of the ECHR would shift from "nothing" to "some").

85 This is, for instance, what inspired projects such as the Siracusa Principles on the Limitation and Derogation Provisions in the International Covenant on Civil and Political Rights, UN Doc. E/CN.4/ 1985/4, Annex (1985) and the International Law Association's Paris Minimum Standards of Human Rights Norms in a State of Emergency, 79 American Journal of International Law (1985) 1072.

86 UN Doc. E/CN.4/SR.127, supra note 30, at 5.

87 UN Doc. E/CN.4/SR.330, supra note 40, at 7. 
of ill-treatment in the list of non-derogable rights since, he said, during the First World War prisoners of war were mistreated by one of the belligerents and it was only through the use of reprisals that the belligerent was induced to mitigate those practices. ${ }^{88}$ In other words, the same delegate who thought that the Covenant would be suspended in wartime also thought that the Covenant's blanket prohibition of illtreatment would impede belligerent reprisals against prisoners of war (and that this would be a bad thing!), a situation obviously relevant only in wartime. ${ }^{89}$

So let us forget the drafting history-we are, otherwise, only liable to be confused. The travaux of the ICCPR do show us that the drafters intended the ICCPR to continue applying in wartime, and that the Article 4 derogation clause would govern such situations. But that is the sum total of their usefulness. Forget also for the moment the fact that in the vast majority of situations human rights and IHL complement each other well and their rules go in the same basic direction. Rather, let us consider two problems where the regime-specific rules do not go in the same direction-killing and detention. These are the hardest cases, in which the danger of a norm conflict is the most acute. I have explained elsewhere that states are perfectly capable of assuming contradictory obligations, and that we should not assume that the diffuse and decentralized international law-making processes will necessarily always lead to a unified, coherent system. ${ }^{90}$ Coherence is not an inevitability, and there may be norm conflicts which are both unavoidable and unresolvable.

But, even so, let as assume that through the adoption of human rights states could not have intended to completely outlaw status-based targeting or preventive security detention in armed conflict. At the very least, states must have in some circumstances retained the liberty to kill combatants merely on the grounds that they are combatants, without inquiring into whether they pose an imminent threat to another person or could be neutralized in some other way, or to detain prisoners of war until the cessation of active hostilities merely because they otherwise might rejoin the enemy. Yet, on the other hand, the text and the logic of human rights treaties can run against this outcome, ${ }^{91}$ and we need to establish how we can avoid the position that the same conduct would inevitably be lawful under IHL, but unlawful under international human rights law (IHRL). Clearly, this will be an explicitly result-oriented analysis, in the sense that one particular outcome would be regarded as absurd, and any interpretative chain that led to that outcome would be suspect.

88 UN Doc. E/CN.4/SR.195, supra note 16, at 22, para. 132.

89 Incidentally, both the Convention Relative to the Treatment of Prisoners of War 1929 (Art. 2(3)) and the Convention (III) Relative to the Treatment of Prisoners of War 1949 (Art. 13(3)) expressly prohibit reprisals against prisoners of war.

90 See Milanovic, supra note 2, at $229 \mathrm{ff}$.

91 See, e.g. Krieger, supra note 82, at 423: 'When comparing both regimes, it follows that security detention under international humanitarian law could hardly meet the standards of Article 5 ECHR since it is not related to a specific offence. There is no prospect that detainees are promptly brought before a judge and the sufficient preciseness of the laws of war is at least doubtful.' 
To appreciate the full complexity of the problem and the possible solutions, let us thus consider killing and preventive detention-both presumptively lawful under IHL but potentially unlawful under IHRL - in four factual scenarios, progressing from the easiest to the most difficult:

(A) Killing and detention in a NIAC on the state's territory-for example, Russia targeting or detaining the members of rebel armed group during the conflict in Chechnya;

(B) Killing and detention in an IAC on the state's territory-for example, if Georgian soldiers fired at or detained a Russian soldier on Georgian territory during the 2008 conflict;

(C) Killing and detention in an IAC outside the state's territory-for example, looking at the Georgian conflict from the Russian perspective, or if UK or US soldiers killed or detained Iraqi combatants during the 2003 invasion of Iraq;

(D) Killing and detention in a NIAC outside the state's territory-for example, if US or UK troops killed or detained a Taliban insurgent in Afghanistan in say 2010.

Again, assume that in all of these scenarios the conduct in question is lawful under IHL, but is potentially unlawful under IHRL. For instance, the persons killed were undoubtedly combatants (in IACs) or fighting members of an armed opposition group (in NIACs), with all IHL rules on targeting complied with, but they were killed while they were sleeping in their barracks (for example, by an air strike) and posed no immediate threat to anyone else, and perhaps could even have been captured. ${ }^{22}$ Similarly, with regard to detention, the persons in question were lawfully detained under IHL for the duration of the hostilities to prevent them rejoining the enemy, but they were charged with no crime and were provided with no judicial review of their detention. So what are our options for dealing with this apparent norm conflict?

Option 1: deny that the human rights treaties apply. The easiest way of avoiding the conflict, superficially at least, is to deny that human rights treaties even apply to the four scenarios. Some states, such as the United States and the United Kingdom, chose this option as their first (and sometimes only) line of defence. There are two basic ways of making this argument. The first is to reject the extraterritorial application of human rights treaties. But while that would dispose of scenarios $\mathrm{C}$ and $\mathrm{D}$, it would leave scenarios $\mathrm{A}$ and $\mathrm{B}$ unaffected. The second is to claim that IHL completely displaces or excludes human rights treaties-this argument is sometimes made by reference to lex specialis, and I will call this approach lex specialis as total displacement. ${ }^{93}$

92 The mainstream IHL position would be that it would be perfectly lawful to make sleeping combatants the object of attack. For a more limited approach to IHL targeting rules combined with the unnecessary suffering principle, see Goodman, 'The Power to Kill or Capture Enemy Combatants', 24 European Journal of International Law (2013) 819.

93 See also Serdar Mohammed v. Ministry of Defence, supra note 66, paras $273 \mathrm{ff}$. 
Both variants of the first option are becoming increasingly unsustainable. In particular, the opponents of extraterritorial application have not been able to offer a convincing normative explanation as to why human rights should stop at the border, ${ }^{94}$ and the case-law is certainly trending towards a more expansive approach to extraterritoriality. States thus have to argue this point in increasingly narrowing terms, for example, that even though the treaties would apply in an occupied territory, they would not apply to air strikes in an area not under the state's effective control. ${ }^{95}$ But again, this approach is likely to fail in the long term. I have argued, for instance, that at a minimum the negative obligations of state (for example, the obligation not to deprive people of their lives or liberty without sufficient justification) should apply without any territorial limitation. ${ }^{96}$ But even on a more modest approach the treaties will at the very least apply to operations in an occupied territory or territory under some other form of de facto control, per the spatial model of jurisdiction as effective control over areas. ${ }^{97}$ They will also apply to the detention of individuals under the personal model of jurisdiction as authority and control over persons. ${ }^{98}$ Whether they would also apply to killing under the personal model of jurisdiction in the absence of territorial control is thus to an extent beside the point for the purpose of this chapter (but they would). Hence, for the purpose of further discussion I will assume that human rights treaties do apply to all four scenarios, and that this avoidance option is unavailable.

94 Consider, in that regard, the leak of internal memoranda written by Harold Koh, then the US State Department Legal Adviser, arguing for the US government to drop its opposition to the extraterritorial application of human rights treaties. See Savage, 'U.S. Seems Unlikely to Accept That Rights Treaty Applies to Its Actions Abroad', The New York Times, 6 March 2014, available online at http://www.nytimes.com/2014/03/07/world/us-seems-unlikely-to-accept-that-rights-treaty-appliesto-its-actions-abroad.html? r $=0$ (last accessed 23 July 2015); Memorandum Opinion on the Geographic Scope of the International Covenant on Civil and Political Rights, U.S. Department of State, Office of the Legal Adviser, 19 October 2010, available online at http://justsecurity.org/wp-content/ uploads/2014/03/state-department-iccpr-memo.pdf (last accessed 23 July 2015); Memorandum Opinion on the Geographic Scope of Application of the Convention Against Torture and Its Application in Situations of Armed Conflict, U.S. Department of State, Office of the Legal Adviser, 21 January 2013, available online at http://justsecurity.org/wp-content/uploads/2014/03/state-department-cat-memo. pdf (last accessed 23 July 2015); Milanovic, 'Harold Koh's Legal Opinions on the US Position on the Extraterritorial Application of Human Rights Treaties', Just Security, 7 March 2014, available online at https://www.justsecurity.org/8010/harold-kohs-legal-opinions-position-extraterritorial-applicationhuman-rights-treaties (last accessed 23 July 2015).

95 For example, the UK government has argued that the ECtHR's Al-Skeini judgment is confined only to the facts of Iraq, and that the ECHR would not apply to UK forces in Afghanistan - see Communication from the United Kingdom concerning the case of Al-Skeini against United Kingdom to the Committee of Ministers, DH-DD(2012)438, 2 May 2012, available online at https://wcd.coe. $\mathrm{int} / \mathrm{com}$.instranet.InstraServlet? command $=$ com.instranet.CmdBlobGet\&InstranetImage $=2082643 \&$ SecMode $=1 \&$ DocId $=1885434 \&$ Usage $=2$ (last accessed 23 July 2015) ('The UK considers that the $A l$ Skeini judgment is set in the factual circumstances of UK's past operations in Iraq and that it has no implications for its current operations elsewhere, including in Afghanistan').

96 See Milanovic, supra note 2.

97 See ECtHR, Loizidou v. Turkey, Appl. no. 15318/89, Judgment (preliminary objections) of 23 February 1995, para. 62.

98 See HRC, Sergio Euben Lopez Burgos v. Uruguay, Comm. no. R.12/52, UN Doc. Supp. No. 40 (A/36/40), 6 June 1979, at 176 (1981), paras 12.2-12.3; IACHR, Coard et al. v. United States, Case no. 10.951, Report No. 109/99, 29 September 1999, para. 37; ECtHR, Al-Skeini v. United Kingdom, Appl. no. 55721/07, Judgment of 7 July 2011, paras 133-137. 
As for the total displacement variant of lex specialis, ${ }^{99}$ it is even less plausible. It stems from the rigid classical divide between the law of war and the law of peace (which would most certainly have no relevance to NIACs, a concept post-dating that rigid divide), has no support in any formal source of modern international law, is contradicted by the text of the derogation clauses themselves, and has been rejected as such by the ICJ and virtually all other authorities.

Option 2: interpret human rights treaties in light of IHL. The second option would be to interpret the substantive standards of IHRL while taking into account the relevant rules of IHL. Thus, in assessing whether a killing is 'arbitrary' in the sense of Article 6(1) ICCPR, we would rely on the rules of IHL on targeting, precautions in attack, prohibited weapons, etc. This is in fact precisely what the ICJ did in its Nuclear Weapons Advisory Opinion. ${ }^{100}$ We can call this approach lex specialis as an aid to interpretation or a rule of norm conflict avoidance. This weak version of lex specialis is in my view unobjectionable, ${ }^{101}$ but it is also one of limited utility. Firstly, it assumes that the test of arbitrariness will necessarily always be confined only to the rules of IHL. In other words, that the ICCPR or the ACHR could not impose any further conditions for a non-arbitrary deprivation of life or liberty if IHL applied, regardless of the particular circumstances. ${ }^{102}$ Secondly, we should recall at this time the important textual differences between the ICCPR and the ACHR, on the one hand, and the ECHR on the other, in particular the fact that unlike the other two treaties the ECHR does not employ open standards such as arbitrariness when it comes to deprivations of life and liberty. Articles 2 and 5 ECHR use closed lists of permissible grounds which would exclude targeting on the basis of status alone or preventive security detention, and no amount of interpretation in light of IHL could change that. Put differently, if lex specialis was only an interpretative tool it could not help solve any of the four scenarios under the ECHR, even if it could do

99 For an articulation of this approach, see, e.g. Response of the US to the request for Precautionary Measures on behalf of the detainees in Guantanamo Bay, Cuba, (2002) 41 ILM 1015, available online at http://www.derechos.org/nizkor/excep/usresp1.html (last accessed 23 July 2015): '[I]nternational human rights law is not applicable to the conduct of hostilities or the capture and detention of enemy combatants, which are governed by the more specific laws of armed conflict... It is humanitarian law, and not human rights law, that governs the capture and detention of enemy combatants in armed conflict. To the extent the ICJ's decision in the Nuclear Weapons Case implies otherwise, the United States reserves its judgment.' See also the ECtHR's summary of Russia's arguments in Georgia v. Russia (II), supra note 72, para. 69: '[T] he Convention did not apply to a situation of international armed conflict where a State Party's forces were engaged in national defence, including in respect of any required operations abroad. In such circumstances the conduct of the State Party's forces was governed exclusively by international humanitarian law.'

100 Nuclear Weapons, supra note 9, para. 25: 'In principle, the right not arbitrarily to be deprived of one's life applies also in hostilities. The test of what is an arbitrary deprivation of life, however, then falls to be determined by the applicable lex specialis, namely, the law applicable in armed conflict which is designed to regulate the conduct of hostilities. Thus whether a particular loss of life, through the use of a certain weapon in warfare, is to be considered an arbitrary deprivation of life contrary to Article 6 of the Covenant, can only be decided by reference to the law applicable in armed conflict and not deduced from the terms of the Covenant itself.'

101 See, e.g. Milanovic, supra note 2, at $249 \mathrm{ff}$, and the sources cited therein; Moir, supra note 15, at 192-193, 207 and 212.

102 Consider, for example, the possibility of capturing the soldiers sleeping in the barracks if this operation would pose little or no risk to the forces of the adversary. 
so under the ICCPR and the ACHR, nor could it for that matter remove the explicit requirements of judicial review of detention in all three treaties.

Option 3: Option 2 plus derogation. The third approach would complement the second option with derogations, whether the situation is territorial or extraterritorial. Thus, while the right to life is non-derogable in the ICCPR and the ACHR even in times of war or armed conflict, it is derogable in the ECHR. Hence, a state that wished to liberate itself from the constraints of Article 2 ECHR and rely on IHL as much as possible would need to derogate from that article. ${ }^{103}$ One issue, as we have seen, is whether the reference to 'lawful acts of war' in Article 15(2) ECHR would encompass both IAC and NIAC. If that reference is limited to IACs only, killing in NIACs would need to comply with stricter standards as no possibility of derogation would be available. Similarly, an ECHR state party that wanted to have recourse to preventive detention would need to derogate from Article 5, and states would need to derogate from all of the treaties if they wanted to suspend or significantly delay judicial review of detention. In all of these situations, states would need to show that the derogation measures were strictly required by the exigencies of the situation.

Option 4: lex specialis as partial displacement. The fourth option would conceive of lex specialis not merely as a guide to interpretation, but as a rule of norm conflict resolution. In case of a genuine conflict between rules of IHL and IHRL, for instance with respect to killing or detention, conflict that could not be avoided through interpretation alone (because, for example, the text of Article 2 ECHR could not be stretched enough to accommodate the IHL approach to targeting, and/or because extraterritorial derogations would be unavailable), then the more 'special' IHL rule would displace or prevail over the inconsistent IHRL rule. ${ }^{104}$ Regardless of the highly problematic construction of a hierarchical relationship between the general and the special, one issue with this approach is that it is unclear, even among its adherents, whether it would apply in the same way to IACs and to NIACs. Recall that at the moment of the creation of NIAC as a legal concept, Common Article 3 of the Geneva Convention was the sum total of all international law applying to NIACs. There were originally, in other words, no 'special' rules of the IHL of NIACs, say on targeting, that could override IHRL. While the customary law of NIACs has developed largely by analogy to IACs, it has done so relatively recently, and significant differences between the two types of armed conflict remain. It is thus perfectly possible to argue that lex specialis as partial displacement option is available for IACs only, in which IHL confers positive entitlements to the belligerent states.

But the bigger problem with this approach is that there is simply no support in any formal source of international law for the proposition that lex specialis is a rule of norm conflict resolution capable of overriding the clear text of conflicting treaty merely on grounds of 'specialness,' however exactly defined. Neither the VCLT nor any other treaty even mention lex specialis. As we have seen, it has been used by the ICJ in the Nuclear Weapons opinion only as an aid to interpretation, to fill in the

103 See Sari, supra note 6, paras 11-14.

104 See, e.g. Sassòli, supra note 67, at 71-73; Roxstrom et al., supra note 6, at 120-121. 
arbitrariness standard in Article 6 ICCPR, which created a window through with IHL could enter. The ICJ never ruled that IHL as lex specialis could punch a hole through the wall where no such window existed. And indeed applying this option to Article 2 ECHR would render the availability of derogations with respect to deaths resulting from lawful acts of war under Article 15(2) ECHR entirely superfluous. If lex specialis was so powerful as to create unwritten exceptions from Article 2, what purpose would have been served by the derogation clause?

Option 5: interpretation as amendment. This final option would essentially lead to the same outcomes as option 4, but without relying on the formal device of lex specialis as a (supposed) tool of norm conflict resolution. The appeal of lex specialis lies precisely in the fact that it lends the appearance of objectivity, of some kind of mathematical or logical inquiry into what is special and what is general, and thus hides patently political judgments behind the veneer of a catchy Latin phrase. But a court (or some other authoritative interpreter) may decide to dispense with the obfuscation and openly choose to 'read down' a categorical text so that it includes some unwritten exceptions in order to avoid results that the court considers unreasonable or impracticable. In essence, the text would be amended through interpretation. This is, in fact, precisely what the advocates of lex specialis as displacement want to achieve. The difference is in that this operation would have to be conducted openly, as a series of value or policy choices that it is, ${ }^{105}$ which of course raises legitimacy concerns as to whether courts or other interpreters are entitled to make such choices and on what basis.

These are then the five options we have for dealing with our hard cases. Note that we do not necessarily need to choose one option for dealing with all four scenarios, but that they enable us to understand the linkages between otherwise conceptually distinct questions and to better appreciate the consequences of choosing one option over another. We can see that there is a direct connection between the availability of (extraterritorial) derogations and the effects of the lex specialis principle. A strong version of lex specialis as total or partial displacement makes derogations unnecessary in situations of armed conflict. A weak version of lex specialis as a mere interpretative tool will require derogations in order to enable status-based targeting, or preventive detention, or to suspend judicial review of such detention. ${ }^{106}$ And this would not depend on (extra)territoriality. The choice between weaker or stronger lex specialis would apply equally to scenarios B and C, and A and D. If, in other words, we think a derogation is necessary to allow for status-based targeting under Article 2 ECHR when the hostilities take place within the state party's

105 For an example of this pragmatic approach, see the Amicus Curiae Brief submitted by F. Hampson and N. Lubell in Hassan v. United Kingdom, Appl. no. 29750/09, available online at https://www.essex.ac.uk/hrc/documents/practice/amicus-curae.pdf (last accessed 23 July 2015).

106 Assuming that human rights bodies would permit derogations from judicial review of detention, which they are unlikely to do despite the fact that the right is not expressly specified as non-derogable in the treaties-see General Comment No. 29, supra note 15, para. 16; IACtHR, Habeas Corpus in Emergency Situations, Advisory Opinion, 30 January 1987, decision available online online at http:// www.corteidh.or.cr/docs/opiniones/seriea_08_ing.pdf (last accessed 23 July 2015). 
territory, and that lex specialis is of no help to us there, then that same reasoning would extend to hostilities outside the state's territory.

The real difficulty for the proponents of a strong version of lex specialis is whether the displacement of human rights standards, inconsistent with IHL, would operate in both IACs and NIACs. ${ }^{107}$ Consider, for example, the United Kingdom's position with respect to the situation in Northern Ireland. While many observers believed that the situation at least at some points in time legally qualified as a NIAC, the UK government categorically refused to acknowledge this. But it still sought to have recourse to internment, and in order to do that it derogated from Article 5 ECHR, which would otherwise have prohibited preventive detention-a derogation found to be lawful by the ECtHR. ${ }^{108}$ Now, if the United Kingdom had acknowledged the existence of a NIAC in Northern Ireland, would that have dispensed with the need to derogate from Article 5, as a strong lex specialis would have precluded the wrongfulness of any resort to internment that would comply with IHL? Or would a derogation be necessary in in the undisputed presence of a NIAC? The Northern Ireland situation finds a parallel in Chechnya, with the caveat that, unlike the United Kingdom, Russia never derogated with respect to events in Chechnya itself.

The ECtHR will inevitably have to choose between the options presented above in at least some of the cases currently pending before it, ${ }^{109}$ for instance in the second inter-state case brought by Georgia against Russia, in Hassan v. United Kingdom, ${ }^{110}$ or in the inter-state case brought by Ukraine against Russia. To take the last case as an example, there is little doubt that an IAC existed between Ukraine and Russia at some point in March 2014, even in the absence of intense armed hostilities. ${ }^{11}$ The control established by Russia over Crimea can also be described as a belligerent occupation, ${ }^{112}$ and one that is likely to last for a very long time. Both IHL and the ECHR will hence apply to Russia's conduct in Crimea. Russia thus seized by force Ukrainian military bases in Crimea, capturing and detaining some of the Ukrainian personnel. ${ }^{113}$ Captured Ukrainian soldiers would qualify as

107 See, e.g. Sassòli, supra note 67, at 81-82 and 88-90; Hampson, 'The Relationship between International Humanitarian Law and Human Rights Law from the Perspective of a Human Rights Treaty Body', 90 International Review of the Red Cross (2008) 549, at 563-566.

108 See Ireland $v$. United Kingdom, supra note 61.

109 As of 1 June 2014.

110 Appl. no. 29750/09. See further Milanovic, 'Hassan v. United Kingdom, IHL and IHRL, and Other News in (Extra-)Territoriality and Shared Responsibility', EJIL: Talk!, 18 December 2013, available online at http://www.ejiltalk.org/hassan-v-united-kingdom-ihl-and-ihrl-and-other-news-inextra-territoriality-and-shared-responsibility (last accessed 23 July 2015).

111 See Blank, 'The Continuing Importance of a Low Threshold for LOAC Application in International Armed Conflict', Just Security, 19 March 2014, at https:/www.justsecurity.org/ 8348/guest-post-continuing-importance-threshold-loac-application-international-armed-conflict (last accessed 23 July 2015).

112 Note that under Common Art. 2 of the 1949 Geneva Conventions, the Conventions 'apply to all cases of partial or total occupation of the territory of a High Contracting Party, even if the said occupation meets with no armed resistance' (emphasis added).

113 See, e.g. 'Russian Troops "Overrun Crimea's Feodosia Naval Base"', BBC News, 24 March 2014, available online at http://www.bbc.co.uk/news/world-europe-26710884 (last accessed 23 July 2015). 
prisoners of war under IHL, and could be held under IHL until the cessation of active hostilities. But what about the ECHR? A strong version of lex specialis would remove the categorical prohibition on preventive detention in Article 5, whereas a weak one could not, absent a derogation - the detention would be lawful under IHL, but unlawful under the ECHR. Indeed, this was precisely the finding of the European Commission with regard to Turkey's internment of Cypriot combatants and civilians, which it found could not be justified under Article 5 without a derogation. ${ }^{114}$

Those advocating for a strong version of lex specialis rely precisely on the fact that by and large states do not derogate to enable status-based targeting and security detention in situations of armed conflict, but as I have explained above this failure is not necessarily the result of any agreement among states about the proper scope of the lex specialis principle. And extending the strong version of that principle to NIACs in particular-today much more widespread than IACs-would remove the key safeguards that the derogation process offers. Note in that regard that those who advocate for strong lex specialis in NIACs logically must do so both for NIACs which are purely internal and those that are cross-border in nature. In other words, if one thinks that even though a NIAC existed in Northern Ireland the United Kingdom still had to derogate from Article 5 ECHR in order to resort to preventive security detention, then one must also accept that the United Kingdom had to derogate to authorize such detention in say post-2001 Afghanistan. Lex specialis might vary in strength depending on the type of armed conflict (IAC or NIAC), but it cannot vary depending on whether a human rights treaty is applied intra- or extraterritorially.

My own view is that lex specialis exists only in its weak variant, as an aid to interpretation, ${ }^{115}$ and that even with respect to the arbitrariness standards in the ICCPR and the ACHR the principle will not inevitably mean that IHL-compliant conduct will necessarily also comply with human rights law. Arbitrariness might bring something new to the table. Consequently, derogations-be they internal or extraterritorial-would be a key tool, albeit not an infallible one, in avoiding conflicts between IHL and IHRL, providing not only flexibility for states when they need it the most, but also important substantive and procedural safeguards.

If states refuse to derogate out of political calculation (as they are free to do), ${ }^{116}$ then they must also suffer the consequences of their choice and the application of more stringent human rights scrutiny. In so doing, states expose themselves to the

114 Cyprus v. Turkey, supra note 75, paras 309-312. Hampson considered such a result to be absurd-see Hampson, supra note 107 , at 565 . But there is nothing absurd about states being able to assume more stringent obligations than what IHL allows, especially if they fail to use the derogation mechanism that they themselves have put into place. The outcome would be absurd only if it could not be avoided through derogations, in which case the only option would be resort to a stronger variant of lex specialis.

115 See Milanovic, supra note 2, at 249-260. See also Prud'homme, 'Lex Specialis: Oversimplifying a More Complex and Multifaceted Relationship?’, 40 Israel Law Review (2007) 356.

116 See Dinstein, supra note 23, at 74 (arguing that that the fact that a derogation can be validly made does not mean that the state will indeed make it, as this is a matter of its own discretion and judgment). 
risk that the same conduct may be lawful under IHL, but not lawful under IHRL. I do not think there is anything unnatural, anomalous or unreasonable about such a result. After all it is international law orthodoxy to say that the same conduct can be lawful under the jus in bello but unlawful under the jus ad bellum, and vice versa. The same logic applies to the relationship between IHL and IHRL, since states can freely assume contradictory commitments, and have only themselves to blame if they do not use the tools that the treaties foresee for avoiding such norm conflicts.

\section{The Link to Sovereignty and the Jus ad Bellum}

The final relationship that I want to examine is precisely that between extraterritorial derogations and legitimacy of government and/or possible violations of the jus ad bellum. One possible objection to extraterritorial derogations is that because they involve the diminishment of human rights, it is only the legitimate government of a territory which can undertake them. At the very least, an intervening state that violates the UN Charter and other rules of the jus ad bellum should not be permitted to invoke derogations - an aggressor has no right to liberalize the rules on the use of force or on the deprivation of liberty just because this would suit its interests. Thus, for example, Russia would have no right to derogate with regard to the situation in Crimea even if it wanted to, nor could the UK government have derogated for the situation in Iraq which it had invaded unlawfully.

Support for this view can be found in the text of the derogation clauses themselves, when they provide that derogation measures must not be inconsistent with the state's other obligations under international law. Similarly, the object and purpose of human rights treaties is inseparable from the Charter regime and its mission to preserve international peace and security. ${ }^{117}$ Finally, there are several points in the drafting history during which some state delegations argued—without opposition-that references to 'war' should be understood as requiring compliance with the Charter regime, for example, as to a purely defensive war. ${ }^{18}$

But this objection could be met with several counter-arguments. Firstly, derogations only concern the relationship between the derogating state and the individuals concerned, not the territorial government which may or may not be temporarily or permanently displaced, in whole or in part. The extent of the United Kingdom's obligations under the ECHR towards the people of Iraq should depend only on an objective assessment of the exigencies of the situation. Secondly, the derogation clauses only require the derogation measures, not the wider context in which they

\footnotetext{
117 For arguments along those lines, see, e.g. Wilde, supra note 82, at 652-656; El Zeidy, supra note 70, at 291-292; Da Costa, supra note 6, at 135-136; Roxstrom et al., supra note 6, at 118-119; Schabas, 'Lex Specialis? Belt and Suspenders? The Parallel Operation of Human Rights Law and the Law of Armed Conflict, and the Conundrum of Jus ad Bellum', 40 Israel Law Review (2007) 592; Bennoune, 'Toward a Human Rights Approach to Armed Conflict: Iraq 2003', 11 U.C. Davis Journal of International Law and Policy (2004) 171, 213-216.

118 See supra notes 30 and 40.
} 
are implemented, such as to the initial decision to use force against another state, to be consistent with the state's other obligations under international law. Thirdly, because jus ad bellum issues can be both politically and legally complex and controversial, insulating human rights from the jus ad bellum can help preserve the integrity of human rights and the institutional competence of human rights bodies. ${ }^{19}$ This is precisely why, for example, the European Commission did its best to avoid considering jus ad bellum legality of the Turkish invasion of Cyprus in its consideration of Article 15,120 and why the ECtHR in Loizidou found that the ECHR would apply extraterritorially whenever a state exercises effective control of an area, whether that control was obtained lawfully or unlawfully under the jus ad bellum, i.e. regardless of whether Turkey had the right to invade Cyprus. ${ }^{121}$ That same principle can be extended to derogations, which would depend on a purely factual relationship between the governor and the governed.

In other words, just like we can separate the jus in bello from the jus ad bellum, so can we separate human rights from the jus ad bellum. Whether we should do this or not is - yet again — a choice. Integrating IHRL with the jus ad bellum would send a symbolic message about the importance of the convergence between the ideals of peace and human rights. It may provide a disincentive to states against breaching the Charter, if they would also be subject to human rights scrutiny in doing so, but it could also render derogations ineffective and lead to a spiral of non-compliance. For example, whatever the United Kingdom did in Iraq after invading it unlawfully would be tainted by the initial illegality and breach of the Charter, and would be hard or impossible to justify under the ECHR—at least until a new Iraqi government emerged that validly consented to the presence of British troops on its territory, or such presence obtained the explicit approval of the Security Council. Similarly, Russia's aggression on Ukraine would render any killing or detention of a Ukrainian soldier by Russian forces unlawful under the ECHR, and so on.

Alternatively, we could treat IHRL just as we treat IHL, and insulate both from jus ad bellum considerations as far as possible. The domain of human rights proper would be the treatment of individuals qua individuals by the state, not subject to the inter-state concerns of the jus ad bellum, which are better dealt with through the substantive rules and institutions established for that purpose. In any event, both options can be legitimately argued for.

119 See Macdonald, supra note 38, at 247: 'This [jus ad bellum legality], I believe, is not a question for the Strasbourg Court. The issue is intrinsically political and too far removed from the main task with which the Convention is concerned'; Harris, supra note 1, at 638: 'Such matters are for the UN Security Council and the consideration of them by the Strasbourg authorities would raise enormously complicated problems of fact-finding and intricate legal questions'; Ergec, supra note 1, at 129-134.

120 For example, in one of the inter-state cases the Cypriot government did argue that derogations were not permissible in aggressive wars-see Cyprus v. Turkey, supra note 75, para. 512, an argument that the Commission avoided as it found that Turkey had not resorted to derogation in the first place.

121 Loizidou, supra note 97, para. 62: 'Bearing in mind the object and purpose of the Convention, the responsibility of a Contracting Party may also arise when as a consequence of military actionwhether lawful or unlawful-it exercises effective control of an area outside its national territory. The obligation to secure, in such an area, the rights and freedoms set out in the Convention, derives from the fact of such control whether it be exercised directly, through its armed forces, or through a subordinate local administration.' 


\section{Conclusion}

The problem of extraterritorial derogations presents us with a series of choices, choices which cannot be made merely on formal grounds. The question really is whether we want extraterritorial derogations, and for what purpose. In answering that question we must strive to balance universality and effectiveness, and find a solution which is fair, practicable, predictable and legally sound. Allowing for a more expansive use of derogations in an extraterritorial setting could promote these goals, especially if derogations as resorted to by states with strong domestic courts and democratic institutions, ${ }^{122}$ but it could also lead to an increase in the abuse of derogations, both internally and externally. At the same time, the differences between the ICCPR and the ACHR on the one hand, and the ECHR on the other, allow us to better appreciate the distinctions between weaker and stronger variants of lex specialis. In doing so, the choice becomes clearer: opting for a weaker variant of lex specialis, or a stronger one that would apply only to IACs, will of necessity require recourse to extraterritorial derogations in we want to enable ECHR states parties to engage in status-based targeting and administrative detention in cross-border NIACs. ${ }^{123}$ Conversely, a stronger version of lex specialis-with all its faults and the uncertainties it brings-would make extraterritorial derogations less necessary.

At present, human rights courts and treaty bodies have yet to adopt a clear approach on these sets of issues and choose between the options that are available to them. Until relatively recently there was little need to do so. When, for example, during the first Gulf War the UK government preventively detained 35 Iraqis studying at British universities as prisoners of war, on the basis of their real or supposed ties with the Iraqi military, and did so without derogating from the ECHR, nobody thought of challenging the Article 5 compliance of that detention before the ECtHR. ${ }^{124}$ But that has changed. Bearing in mind not only the cases

122 See Hafner-Burton, Helfer and Fariss, 'Emergency and Escape: Explaining Derogations from Human Rights Treaties', 65 International Organization (2011) 673 (arguing that it is precisely such states that will most frequently resort to derogations, since they possess 'compliance constituencies' that can hold governments to account for repressing individual rights, whereas authoritarian states will violate individual rights with or without derogations).

123 Other options, such as security detention clearly and expressly authorized by the Security Council, which could potentially prevail over human rights treaties by virtue of Art. 103 of the Charter, are not only fraught with their own conceptual problems but are unlikely to provide a systematic solution, since they depend on the agreement of the Council members to pass such an unambiguous resolution.

124 On this episode see especially Risius, 'Prisoners of War in the United Kingdom', in P. Rowe (ed.), The Gulf War 1990-91 in International and English Law (1993) 255. The author wisely declined to discuss the impact, if any, of the ECHR and the ICCPR on the internment of these individuals. The United Kingdom also detained a number of Iraqi civilians, but it did not do so on the basis of the internment provisions of the Fourth Geneva Convention, but rather did so under immigration law, pending their deportation from the United Kingdom. Such detention could be accommodated under Art. 5(1)(f) ECHR, and would accordingly not pose the derogation/relationship with IHL problem. See further Walsh, 'Detention and Deportation of Foreign Nationals in the United Kingdom during the Gulf Conflict', in ibid., 268; 'Middle East Watch condemns Great Britain for holding 35 Iraqi 
that are currently pending, but the inevitability of other cases that will follow, the time for making that choice is now. This is especially true of the ECtHR, whose longstanding (if understandable) evasiveness with regard to explaining the relationship between IHL and the ECHR soon must come to an end. ${ }^{125}$

residents as prisoners of war and detaining dozens of Arabs for deportation', Human Rights Watch Newsletter, 10 February 1991, available online at http://www.hrw.org/reports/pdfs/u/uk/uk912.pdf (last accessed 23 July 2015); Roberts, 'The Laws of War in the 1990-91 Gulf Conflict', 18 International Security (1993) 134, at 153-154.

125 In that regard, the ECtHR's presumption of compatibility in Al-Jedda, supra note 19, para. 102 is squarely directed at the interpretation of Security Council resolutions in the context of Art. 103 of the Charter, and should not be taken as any kind of general statement regarding the ECHR's relationship with IHL - but see Pejic, 'The European Court of Human Rights' Al-jedda Judgment: The Oversight of International Humanitarian Law', 93 International Review of the Red Cross (2011) 837. If the Court wanted to, it could still find that IHL rules on internment trump Art. 5 ECHR by virtue of a strong lex specialis without having to depart from Al-Jedda (although I think it should not do so). 